\title{
Relationship between milk urea, blood plasma urea and body condition score in primiparous browsing goats with different milk yield level
}

Michele Pazzola, Maria Luisa Dettori, Vincenzo Carcangiu, Sebastiano Luridiana, Maria Consuelo Mura and Giuseppe Massimo Vacca

Department of Animal Biology, University of Sassari, Sassari, Italy

\begin{abstract}
The aim of this study was to investigate the relationships among milk urea, blood plasma urea, milk yield and body condition score (BCS) in primiparous goats fed at pasture. Ninety goats of Sarda breed were used and, on the basis of their yield level, divided in three groups of 30 animals each, low (LY), intermediate (IY) and high milk yield (HY). Daily milk yield, milk protein content, milk urea, plasma total protein and albumin, plasma urea and BCS were measured at monthly intervals from 45 days in milking (45 DIM) to 165 DIM. Milk yield level affected protein concentration of milk and plasma, whereas albumin showed no variation. Plasma and milk urea showed a high correlation $(P<0.001)$ despite of the yield level; plasma urea was always lower than milk urea. BCS decreased on 75 DIM and again after 135 DIM, and it was not affected by the milk yield level. Because milk urea and plasma urea were closely correlated and not influenced by the yield level, the study pointed out that measurement of milk urea could be utilized to evaluate urea metabolism also for browsing goats.
\end{abstract}

Keywords: goat, urea, milk yield, extensive breeding

\section{Zusammenfassung}

\section{Zusammenhang zwischen Milchharnstoff, Blutplasmaharnstoff und Konditionsbeurteilung von erstlaktierenden Ziegen in Weidehaltung mit unterschiedlicher Milchleistung}

Ziel der Untersuchung war es, die Beziehungen zwischen Milch- und Blutplasmaharnstoff, Milchleistung und Körperkondition (BCS) von Ziegen in Weidehaltung während der ersten Laktation zu erforschen. Neunzig Ziegen der Rasse Sarda wurden ausgewählt und auf der Grundlage ihrer Milchleistung in drei Gruppen von je 30 Tieren eingeteilt: Niedrig(LY), Mittel-(IY) und Hochleistung (HY). Tägliche Milchleistung, Milcheiweiß, Milchharn, Gesamtplasmaprotein, Albumin, Plasmaharnstoff und BCS wurden in monatlichen Abständen von 45 bis 165 Tagen während der Laktation (DIM) gemessen. Die Höhe der Milchleistung beeinflusste die Proteinkonzentration von Milch und Plasma. Dagegen veränderte sich die Albuminkonzentration nicht. Milch- und Plasmaharnstoff besaßen trotz unterschiedlicher Milchleistung einen hohen Korrelationskoeffizienten $(P<0.001)$. Plasmaharnstoff war dabei immer niedriger als Milchharnstoff. Der BCS sank bei 75 DIM und wieder bei 135 DIM, und 
wurde nicht beeinflusst durch die Höhe der Milchleistung. Auch die enge Wechselbeziehung zwischen Milch- und Plasmaharnstoff wurden durch die Höhe der Milchleistung nicht betroffen. Die Studie zeigt, dass die Messung von Milchharnstoffs genutzt werden könnte, um den Harnstoffwechsel auch bei Ziegen in Weidehaltung zu bewerten.

Schlüsselwörter: Ziege, Harn, Milchleistung, extensive Zucht

\section{Introduction}

Goat breeding is a significant sector of animal production in the European Union and the leading countries in goat milk and cheese production are France, Greece, Spain, Bulgaria and Italy (FAOSTAT 2008). In these countries, goats are reared through intensive or extensive methods and using different breeds adapted to either of these methods. The extensive method is mostly restricted to marginal areas and local breeds are exploited. The region of Sardinia, Italy, possesses 291000 heads (IZS 2008) producing about $20 \%$ of Italian goat milk, which is mainly transformed into cheese. The Sarda goat is the autochthonous breed from this area and is characterized by significant differences on productive basis (Vacca et al. 2006), even though, for the genetic improvement, breeders are used to choose the replacement rate among those goat kids which are born by the high yielding does. Animal feeding in traditional Sardinian goat breeding is almost exclusively based on grazing natural pasture of the Mediterranean maquis, and supplementary feed is rarely used (Carcangiu et al. 2006). Under such conditions, the evaluation of correct feeding and feed intake is extremely difficult but necessary during some productive stages such as pregnancy or lactation. For this purpose the analysis of some parameters are currently used in ruminants nutrition. Body condition score (BCS) is an important parameter commonly utilized in the field of nutrition for dairy cattle and sheep to evaluate the right feed needs (Ngwa et al. 2007). BCS is affected by nutrition and productive stages and in ewes is closely related with hormones and plasma metabolites such as urea (Caldeira et al. 2007). It could also be a suitable tool in extensive goat breeding to evaluate and correct nutritional imbalances (Cabiddu et al. 1999). In this species, the risk of diminishing reproductive performance is influenced by BCS, above all among the primiparous does, as they need a greater nutrient demand than multiparous animals (Mellado et al. 2004). Together with BCS, urea and its cycle is another important tool to assess optimal feeding of livestock. In ruminants, urea is formed in the liver from nitrogen as ammonia and nitrogen derived from the deamination of aminoacids, and it is excreted by the kidney in the urine but also into the rumen, where it is delivered through the blood vascular system (Cunningham 2002). Protein content in diet affects urea recycling rate and plasma urea concentration. Indeed, protein can be produced in the rumen from urea and other nitrogen sources and the flow of urea is from the rumen to the blood and vice versa (Harmeyer \& Martens 1980, Cunningham 2002). Plasma urea is positively correlated to milk urea in cows (Roseler et al. 1993, Butler et al. 1996, Broderick \& Clayton 1997), sheep (Cannas et al. 1998) and goats (Cabiddu et al. 1999, Bava et al. 2001, Sahoo \& Walli 2008). Given that milk is easier to collect than blood, milk urea is a suitable parameter to evaluate urea metabolism, especially on a herd level (Schepers \& Meijer 1998), both in intensive and extensive dairy farms. Concentration of plasma and milk urea are also 
related to the yield level. In general, lactating goats with high milk yield have an improved efficiency in urea and nitrogen recycling rate compared to lactating goats with low yield (Brun-Bellut 1996).

Thus, due to the limited information on the relationship between milk production, urea metabolism and BCS in goats at first lactation kept under extensive conditions, this research was carried out to investigate the relationship among urea concentration in milk and blood plasma, milk yield level and BCS in browsing Sarda goats throughout the first lactation.

\section{Material and methods}

\section{Animals}

The study was conducted on a commercial goat farm located in southwest Sardinia, Italy $\left(39^{\circ} 00^{\prime} \mathrm{N} ; 8^{\circ} 40^{\prime} \mathrm{E}\right)$. This area is characterized by a mild climate and the annual rainfall is concentrated in the months of October to April; mean maximum temperature and mean relative humidity during the wet and the dry season are respectively as follows: $8-14{ }^{\circ} \mathrm{C}, 70$ $80 \% ; 18-24^{\circ} \mathrm{C}, 50-65 \%$. The herd was allowed to browse about 750 ha with an elevation range between 400 and $700 \mathrm{~m}$ above sea level. The herd was made up of 450 goats and 20 bucks of Sarda breed. Animal management was in accordance with traditional Sardinian goat farming: goats were exclusively fed pasture, no concentrate supplementation was used; they were hand-milked once daily $(9: 00 \mathrm{am})$ and the udder was not cleaned before milking; reproduction was based on natural mating; kids were milk fed by their dams and weaned when they were about 6 weeks old. Some pens and a shelter for milking were the only facilities on the farm. 90 primiparous goats, with a live weight of $33 \pm 2 \mathrm{~kg}$ (mean \pm standard deviation), whose parturition occurred in the month of February, were randomly selected for the study. The animals had no evidence of clinical disease or mastitis throughout the study.

\section{Samples and analysis}

Milk samples were taken throughout the entire lactation period of the goats. Lactation of all browsing goats in Sardinia, in spite of their breed, has a duration which depends by the kidding date, which generally occurs from November to February, and by the availability of pasture. Indeed, in Sardinia, which is a semi-arid area (Boyazoglu \& Morand-Fehr 2001), natural pastures are almost desiccated by the months of June and July. After desiccation of pastures, milk production is no more possible and goats enter the dry period. Hence, samples were taken at monthly intervals after the kids were weaned, from the beginning to the end of the lactation, in March (45 days in milking after kidding, 45 DIM), April (75 DIM), May (105 DIM), June (135 DIM) and July (165 DIM). Each month, individual milk samples from each goat were collected in $50 \mathrm{ml}$ sterile plastic containers and transported at $+4^{\circ} \mathrm{C}$ to the laboratory within two hours after collection. On the same day, body condition score (BCS) in accordance with the method described by Santucci et al. (1991) was determined always by the same person, milk yield in grams was registered for each goat and a blood sample from each animal was taken after milking operations, by one puncture from the jugular vein, using vacuum tubes containing heparin (Becton Dickinson, Plymouth, UK). The blood was immediately centrifuged at $3000 \mathrm{~g}$ for $20 \mathrm{~min}$ at $+4^{\circ} \mathrm{C}$, and the plasma was frozen at $-20^{\circ} \mathrm{C}$ until analysis. 
Milk samples were analyzed for protein content using an infrared spectrophotometer (MilkoScan 133B; Foss Electric, DK 3400 Hillerød, Denmark) according to the International Dairy Federation (IDF) standard (IDF 141C:2000). Milk protein yield was calculated multiplying the protein content by the milk yield in grams. Milk urea was determined by the automated test CL-10 (Eurochem, Rome, Italy) which measures the ammonia formed from urea after treating the sample with urease. Plasma samples were analyzed by using the colorimetric diagnostic method (spectrophotometer VITALAB 200R, Vital Scientific, Dieren, The Netherlands; reagents SENTINEL CH, Milan, Italy) for total protein (copper sulfate method), albumin (bromocresol green method) and urea (urease/glutamate dehydrogenase method).

\section{Statistical analysis}

The estimated milk yield of the entire lactation was calculated using the Wood's equation (Wood 1967):

$$
Y=a t^{b} \exp (-c t)
$$

where $Y$ is the daily milk production in grams, $t$ is the time in weeks, and $a, b$ and $c$ are the parameters characterizing the shape of the curve and the ratio $b / c$ represents the production peak. Therefore, goats were divided into three groups, each one made up of 30 animals, on the basis of the estimated total milk yield: low milk yield (LY), intermediate milk yield (IY) and high milk yield (HY). Throughout the study, these three groups were managed together as one group. The data was subjected to the repeated measures analysis of variance (ANOVA) based on the following model:

$$
Y_{i j k}=\mu+M_{i}+Y_{j}+M Y_{i j}+e_{k(i j)}
$$

where $Y_{i j k}$ is the analysed parameters, $\mu$ is the general mean, $M_{i}$ is the fixed effect of the month $(i=5)$ meant as the stage of lactation measured as days in milking (DIM), $Y_{j}$ is the fixed effect of the milk yield level $(j=3), M Y_{i j}$ is the interaction effect between the month and the milk yield level and $e_{k(i j)}$ is the error effect. For all parameters, model effects were declared significant at $P<0.05$. Then, data was processed by the Pearson product moment correlation coefficient to measure the correlation between the variables. Statistical analyses were performed by means of Minitab statistical software (Minitab release 13.32, Minitab Inc. 2000, State College, PA, USA).

\section{Results}

After each goat was allocated into the groups on the basis of its own milk yield level, we obtained three statistically different levels $(P<0.001)$ with the following means and standard deviations of total milk yield: low yield $78.7 \pm 9.9 \mathrm{~kg}$; intermediate yield $115.7 \pm 14.1$; high yield

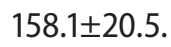

Results for milk parameters are shown in Table 1. Milk protein yield was influenced by yield level $(Y)$ and the stage of lactation meant as days in milking (DIM) $(P<0.01)$ and by the interaction $Y \times D I M(P<0.05)$. The minimum and maximum values of the means were $13.80 \mathrm{~g} /$ day in LY (on 165 DIM) and 41.02 g/day in HY (on 105 DIM), respectively. Milk urea means ranged from $17.15 \mathrm{mg} / \mathrm{dL}$ (HY on 165 DIM) to $27.81 \mathrm{mg} / \mathrm{dL}$ (HY on 45 DIM) and were affected 
by the interaction $Y \times$ DIM $(P<0.05)$. Results for plasma parameters are shown in Table 2 . Plasma total protein was affected by the milk yield level $(P<0.01)$ whereas for albumin no statistical differences were evidenced. Plasma urea was influenced by DIM $(P<0.05)$. Results regarding $B C S$ are summarized in the Figure. BCS was affected by the stage of lactation at $P<0.05$. In the three levels, BCS decreased on 75 DIM, but it rose on 105 DIM and, thereafter, decreased again in the two final stages. The highest (2.77) and the lowest means (2.13), were registered for HY on 45 and 165 DIM, respectively. Table 3 shows correlation coefficients between BCS and parameters of milk and plasma. BCS was positively correlated $(P<0.01)$ to daily milk yield and milk protein yield for HY. Daily milk yield was negatively correlated to milk protein content $(P<0.05$ for IY and HY, $P<0.001$ for $L Y)$; positively to milk protein yield $(P<0.001$ for the three levels); positively to milk urea ( $P<0.01$ for IY, $P<0.001$ for $L Y$ and HY); to albumin (negatively at $P<0.001$ for LY and positively at $P<0.05$ for HY); positively to plasma urea for $\mathrm{HY}$ at $P<0.001$. Milk protein yield was positively correlated to milk urea $(P<0.01$ for $\mathrm{IY}$, $P<0.001$ for $L Y$ and $\mathrm{HY}$ ); negatively to plasma albumin $(P<0.001$ for $L Y)$; positively to plasma urea $(P<0.001$ for $\mathrm{HY}, P<0.05$ for $\mathrm{LY}$ and $\mathrm{IY})$. Milk urea was negatively correlated to plasma albumin $(P<0.05$ for IY) and positively to plasma urea in all the three levels $(P<0.001)$. Plasma total protein was positively correlated to albumin for LY and HY $(P<0.01)$ and plasma urea at $P<0.05$ for LY.

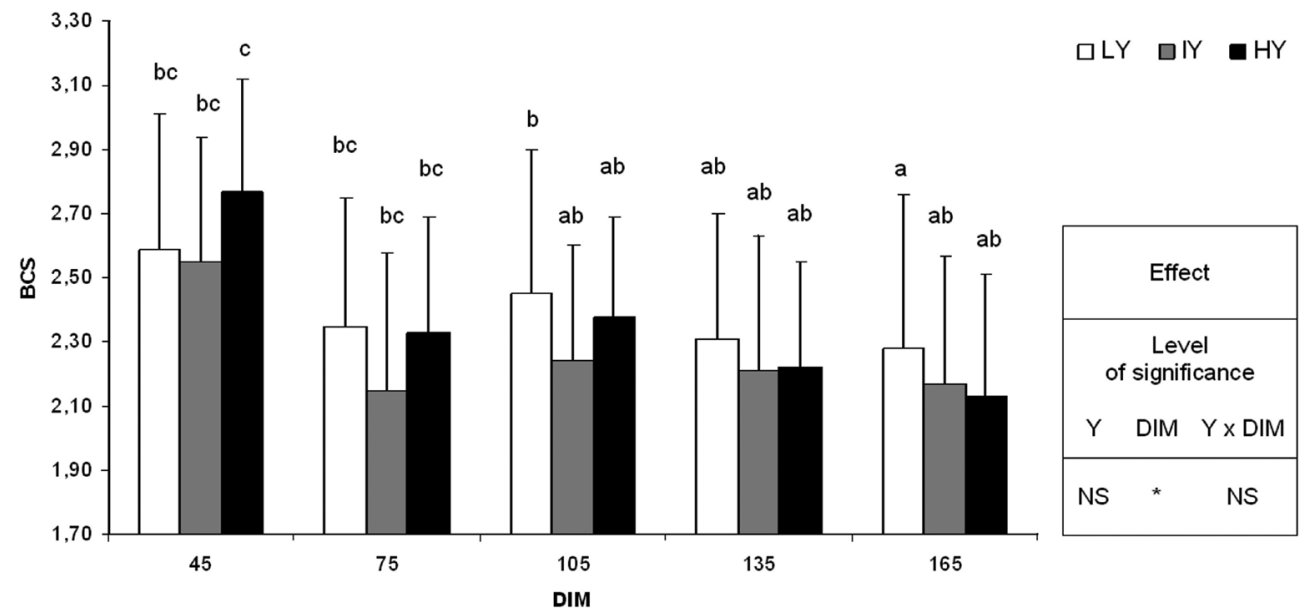

a,b,c different lower-case letters indicate significance at $P<0.05, L Y, I Y, H Y$ : low intermediate and high milk yield, Y: milk yield level, DIM: days in milking meant as the stage of lactation, $Y \times$ DIM: milk yield level $\times$ days in milking, NS: not significant, ${ }^{*} P<0.05$

Figure

Means and standard deviation of body condition score (BCS) throughout the lactation, according to the milk yield level of goats $(n=90)$ 
Table 1

Means and standard error (SE) of protein and urea content of milk throughout the lactation, according to the milk yield level of goats $(n=90)$

\begin{tabular}{|c|c|c|c|c|c|c|c|c|}
\hline & \multirow[b]{3}{*}{$\mathrm{n}=$} & \multicolumn{3}{|c|}{ Milk yield level } & \multicolumn{4}{|c|}{ Effect } \\
\hline & & \multirow{2}{*}{$\begin{array}{l}\mathrm{LY} \\
30\end{array}$} & \multirow{2}{*}{$\begin{array}{l}\text { IY } \\
30\end{array}$} & \multirow{2}{*}{$\begin{array}{l}\text { HY } \\
30\end{array}$} & \multirow[b]{2}{*}{ SE } & \multicolumn{3}{|c|}{ Level of significance } \\
\hline & & & & & & Y & DIM & $Y \times D I M$ \\
\hline Milk protein, $\mathrm{g} / 100 \mathrm{~mL}$ & 45 & $4.54^{\mathrm{BY}}$ & $4.44^{\mathrm{BY}}$ & $4.21^{\mathrm{AZ}}$ & & & & \\
\hline \multirow[t]{4}{*}{ DIM } & 75 & $4.52^{\mathrm{BY}}$ & $4.38^{\mathrm{BY}}$ & $4.12^{\mathrm{AY}}$ & & & & \\
\hline & 105 & $4.45^{\mathrm{BY}}$ & $4.44^{\mathrm{BY}}$ & $4.09^{\mathrm{AY}}$ & & & & \\
\hline & 135 & $4.28^{\mathrm{BX}}$ & $4.21^{\mathrm{BX}}$ & $3.93^{\mathrm{AX}}$ & & & & \\
\hline & 165 & $4.54^{\mathrm{CY}}$ & $4.35^{\mathrm{BY}}$ & $4.06^{\mathrm{AY}}$ & 0.02 & $* *$ & $* *$ & ns \\
\hline Milk protein yield, g/day & 45 & $17.84^{\mathrm{AY}}$ & $27.23^{\mathrm{BY}}$ & $36.12^{\mathrm{CY}}$ & & & & \\
\hline \multirow[t]{4}{*}{ DIM } & 75 & $22.18^{\mathrm{AZ}}$ & $30.20^{B Z}$ & $39.08^{\mathrm{Cz}}$ & & & & \\
\hline & 105 & $22.37^{A Z}$ & $33.16^{\mathrm{BZ}}$ & $41.02^{\mathrm{Cz}}$ & & & & \\
\hline & 135 & $18.02^{\mathrm{AY}}$ & $25.80^{\mathrm{BY}}$ & $32.74^{\mathrm{CY}}$ & & & & \\
\hline & 165 & $13.80^{\mathrm{AX}}$ & $18.27^{\mathrm{BX}}$ & $22.34^{\mathrm{cx}}$ & 0.32 & $* *$ & $* *$ & * \\
\hline Milk urea, mg/dL & 45 & 19.27 & 18.60 & 27.81 & & & & \\
\hline \multirow[t]{4}{*}{ DIM } & 75 & 26.54 & 25.60 & 21.33 & & & & \\
\hline & 105 & 25.63 & 23.57 & 25.88 & & & & \\
\hline & 135 & 22.10 & 19.05 & 21.27 & & & & \\
\hline & 165 & 20.78 & 18.44 & 17.15 & 0.46 & ns & ns & * \\
\hline
\end{tabular}

LY, IY, HY: low intermediate and high milk yield, Y: milk yield level, DIM: days in milking meant as the stage of lactation, $Y \times D I M$ : milk yield level $\times$ days in milking, $A, B, C$ means within the same row followed by different upper-case letters differ significantly $(P>0.01)$ in $Y$ comparison, $x, y, z$ means within the same column followed by different uppercase letters differ significantly $(P>0.05)$ in DIM comparison, ns: not significant, ${ }^{*} P<0.05,{ }^{*} P<0.01$

Table 2

Means and standard error (SE) of plasma concentration of total protein, albumin and urea throughout the lactation, according to the milk yield level of goats $(n=90)$

\begin{tabular}{|c|c|c|c|c|c|c|c|c|}
\hline & \multirow[b]{3}{*}{$\mathrm{n}=$} & \multicolumn{3}{|c|}{ Milk yield level } & \multirow{2}{*}{\multicolumn{4}{|c|}{$\begin{array}{l}\text { Effect } \\
\text { Level of significance }\end{array}$}} \\
\hline & & \multirow{2}{*}{$\begin{array}{l}\mathrm{LY} \\
30\end{array}$} & \multirow{2}{*}{$\begin{array}{l}\text { IY } \\
30\end{array}$} & \multirow{2}{*}{$\begin{array}{l}\mathrm{HY} \\
30\end{array}$} & & & & \\
\hline & & & & & SE & Y & DIM & $\mathrm{Y} \times \mathrm{DIM}$ \\
\hline Total protein, g/dL & 45 & $6.99^{\mathrm{A}}$ & $6.89^{\mathrm{A}}$ & $7.12^{\mathrm{B}}$ & & & & \\
\hline DIM & 75 & $6.99^{\mathrm{A}}$ & $7.02^{\mathrm{A}}$ & $7.34^{\mathrm{B}}$ & & & & \\
\hline & 105 & $7.13^{\mathrm{A}}$ & $7.05^{\mathrm{A}}$ & $7.44^{\mathrm{B}}$ & & & & \\
\hline & 135 & $7.19^{A}$ & $7.04^{\mathrm{A}}$ & $7.41^{B}$ & & & & \\
\hline & 165 & $7.31^{B}$ & $7.11^{\mathrm{A}}$ & $7.45^{c}$ & 0.03 & ** & ns & ns \\
\hline Plasma albumin, $\mathrm{g} / \mathrm{dL}$ & 45 & 3.79 & 3.61 & 3.77 & & & & \\
\hline DIM & 75 & 3.85 & 3.63 & 3.85 & & & & \\
\hline & 105 & 3.88 & 3.70 & 3.97 & & & & \\
\hline & 135 & 3.94 & 3.69 & 3.85 & & & & \\
\hline & 165 & 3.94 & 3.60 & 3.64 & 0.02 & ns & ns & ns \\
\hline Plasma urea, mg/dL & 45 & $13.70^{\mathrm{x}}$ & $12.34^{x}$ & $18.13^{y}$ & & & & \\
\hline DIM & 75 & $19.28^{y}$ & $16.62^{y}$ & $14.75^{x}$ & & & & \\
\hline & 105 & $21.05^{y}$ & $16.87^{y}$ & $18.85^{y}$ & & & & \\
\hline & 135 & $21.71^{y}$ & $18.71^{y}$ & $19.57^{y}$ & & & & \\
\hline & 165 & $22.83^{y}$ & $14.50^{x}$ & $14.86^{x}$ & 0.32 & ns & * & ns \\
\hline
\end{tabular}

LY, IY, HY: low intermediate and high milk yield, Y: milk yield level, DIM: days in milking meant as the stage of lactation, $Y \times D I M$ : milk yield level $\times$ days in milking, $A, B, C$ means within the same row followed by different upper-case letters differ significantly $(P>0.01)$ in $Y$ comparison, ${ }^{x}, y, z$ means within the same column followed by different lowercase letters differ significantly $(P>0.05)$ in DIM comparison, ns: not significant, ${ }^{*} P<0.05, \quad{ }^{* *} P<0.01$ 
Table 3

Correlation coefficients between body condition score (BCS), daily milk yield, milk protein, milk protein yield and urea, plasma total protein, albumin and urea, according to the milk yield level of goats $(n=450)$

\begin{tabular}{|c|c|c|c|c|c|c|c|c|}
\hline & & BCS & $\begin{array}{c}\text { Daily } \\
\text { milk yield } \\
\text { (g/day) }\end{array}$ & $\begin{array}{c}\text { Milk } \\
\text { protein } \\
(\mathrm{g} / 100 \mathrm{~mL})\end{array}$ & $\begin{array}{c}\text { Milk } \\
\text { protein } \\
\text { yield } \\
\text { (g/day) }\end{array}$ & $\begin{array}{c}\text { Milk } \\
\text { urea } \\
(\mathrm{mg} / \mathrm{dL})\end{array}$ & $\begin{array}{c}\text { Plasma } \\
\text { total } \\
\text { protein } \\
(\mathrm{g} / \mathrm{dL})\end{array}$ & $\begin{array}{c}\text { Plasma } \\
\text { albumin } \\
\text { (g/dL) }\end{array}$ \\
\hline \multirow{2}{*}{$\begin{array}{l}\text { Daily milk } \\
\text { yield, g/day }\end{array}$} & LY & 0.177 & & & & & & \\
\hline & IY & -0.051 & & & & & & \\
\hline \multirow{3}{*}{$\begin{array}{l}\text { Milk protein, } \\
\mathrm{g} / 100 \mathrm{~mL}\end{array}$} & LY & -0.081 & $-0.242^{* * *}$ & & & & & \\
\hline & IY & 0.096 & $-0.181^{*}$ & & & & & \\
\hline & HY & 0.142 & $-0.177^{*}$ & & & & & \\
\hline \multirow{3}{*}{$\begin{array}{l}\text { Milk protein } \\
\text { yield, g/day }\end{array}$} & LY & 0.176 & $0.956^{* * *}$ & 0.030 & & & & \\
\hline & IY & 0.002 & $0.973^{* * *}$ & 0.027 & & & & \\
\hline & HY & $0.350^{* *}$ & $0.955^{* * *}$ & 0.101 & & & & \\
\hline \multirow{3}{*}{$\begin{array}{l}\text { Milk urea, } \\
\mathrm{mg} / \mathrm{dL}\end{array}$} & LY & 0.024 & $0.363^{* * *}$ & 0.106 & $0.408^{* * *}$ & & & \\
\hline & IY & -0.076 & $0.253^{* *}$ & -0.020 & $0.260^{* *}$ & & & \\
\hline & $\mathrm{HY}$ & 0.139 & $0.376^{* * *}$ & -0.044 & $0.374^{* * *}$ & & & \\
\hline \multirow{3}{*}{$\begin{array}{l}\text { Plasma total } \\
\text { protein, } \mathrm{g} / \mathrm{dL}\end{array}$} & LY & 0.153 & -0.166 & 0.037 & -0.166 & -0.037 & & \\
\hline & IY & 0.113 & 0.048 & 0.154 & 0.083 & 0.038 & & \\
\hline & HY & 0.114 & -0.013 & -0.042 & -0.019 & -0.069 & & \\
\hline \multirow{4}{*}{$\begin{array}{l}\text { Plasma } \\
\text { albumin, } \mathrm{g} / \mathrm{dL}\end{array}$} & LY & -0.174 & $-0.415^{* * *}$ & 0.116 & $-0.307^{* * *}$ & -0.074 & $0.243^{* *}$ & \\
\hline & IY & 0.118 & 0.036 & -0.022 & 0.027 & $-0.172^{*}$ & 0.145 & \\
\hline & $\mathrm{HY}$ & 0.108 & $0.184^{*}$ & -0.097 & 0.168 & 0.009 & $0.288^{* *}$ & \\
\hline & LY & -0.176 & 0.148 & 0.102 & $0.179 *$ & $0.641^{* * *}$ & $0.179 *$ & 0.055 \\
\hline \multirow{2}{*}{$\begin{array}{l}\text { Blood urea, } \\
\mathrm{mg} / \mathrm{dL}\end{array}$} & IY & -0.024 & 0.161 & -0.004 & $0.171^{*}$ & $0.689 * * *$ & 0.058 & -0.104 \\
\hline & HY & -0.049 & $0.329^{* * *}$ & -0.054 & $0.323^{* * *}$ & $0.848^{* * *}$ & -0.013 & 0.123 \\
\hline
\end{tabular}

LY, IY, HY: low intermediate and high milk yield, ${ }^{*} P<0.05,{ }^{*} P<0.01, * * * P<0.001$

\section{Discussion}

On the whole, milk protein content showed the lowest value from 105 to 135 DIM as it was negatively correlated to milk yield in all the levels. Similar results are obtained for the Alpine breed by Fekadu et al. (2005). On the contrary, milk protein yield, a parameter which can better explain the metabolic effort of protein production, obviously showed a positive correlation with milk yield, and also with milk urea. The positive correlation between milk protein yield and milk urea was in accordance with data registered in dairy cows through three lactations (Richardt et al. 2001). The positive correlation between BCS and daily milk yield seemed to be reversed if we evaluated both the diagram in the Figure and data from Table 1, because the peak of daily milk yield was recorded on the same stages of BCS decrease. This finding should not bring to misinterpretation because the positive correlation derived from the statistical analysis performed using the Pearson product moment correlation coefficient. This test measured the total degree of linear relationship between BCS and daily milk yield within each level, despite of the individual stage of lactation. Means of milk urea were similar to those by Bava et al. (2001) for Saanen goats, with higher milk yield and lower milk protein content. However, the present data were lower than those by Sahoo \& Walli (2008) for crossbred goats and by Cabiddu et al. (1999) for Corsican goats fed exclusively pasture. The positive correlation of milk urea and milk yield in all the three levels indicated that urea recycling rate was irrespective of milk yield. The high correlation of milk urea 
and plasma urea in the current study, using the Sarda goat breed, was the same result as seen in other ruminants species, as in the sheep (Bedö et al. 1997). Consequently, because milk is easier to collect than blood, measurement of milk urea could be utilized also in goat breeding for diagnosis of correct or wrong nutritional status, for prediction of cheese yield and to avoid hypofertility syndrome. Indeed, Cannas et al. (1998) state that, in dairy sheep, milk urea increases linearly as crude protein intake increases and it could be used to estimate the content of crude protein of the diet, also in grazing animals. Moreover, in dairy cows milk urea concentration could be predicted by using other records as milk protein yield, the stage of lactation and somatic cell count (Richardt et al. 2002). In dairy animals which produce milk for cheese-making, milk urea is positively correlated to rennet coagulation time (Gustafsson \& Palmquist 1993) and Butler et al. (1996) record that, in the bovine species, plasma and milk urea concentrations greater than $19 \mathrm{mg} / \mathrm{dL}$ are associated with decreased reproductive performance. Throughout the lactation, milk urea was always higher than plasma urea in all the levels. An analogous characteristic is recorded by Min et al. (2005) in Alpine does, but not by Bava et al. (2001) in Saanen goats when milk urea is constantly lower than plasma urea. It is an uncommon feature also in sheep (Jelínek et al. 1996) and, in dairy cows, the two parameters are habitually correlated in a linear regression (Roseler et al. 1993; Broderick et al. 1997) and milk urea is higher than plasma urea only in particular phase of the day, e.g. after milking, when plasma urea is decreasing (Gustafsson \& Palmquist 1993). In the present study, milk samples were taken in the morning, when goats returned to the farm after they spent the day before at pasture and the night outdoor, and blood samples were collected after the milking operations. Hence, in accordance with the data recorded for dairy cows by Gustafsson \& Palmquist (1993), the time of blood sampling almost certainly caused an elevated urea concentration, which was collected via the blood and excreted via the milk. This consequently affected the concentration of milk and plasma urea.

Plasma albumin did not show any variation as it was less affected by the different stages of physiological processes such as lactation, or by negative energy balance. This is because it is the most important plasma carrier and has an essential role in regulation of blood volume.

The trend of BCS was affected by the stage of lactation as it showed two decreases in all the levels on 75 DIM and once again, after it raised, on 135 DIM. The highest difference between the mean of the values at the start (BCS 2.77) and the end of lactation (BCS 2.13) was registered for HY goats. It can presume that a general cause of BCS falling on 75 DIM could be linked to the ascending phase of lactation. Indeed, after parturition the ruminants generally enter negative energy balance as the nutrient requirement for milk production is often higher than the energy intake (Bauman \& Currie 1980) and growth hormone (GH) promotes the mobilization of fatty deposits to furnish the udder biochemical substrates for the secretory activity (Bell 1995). Whereas, BCS drop after 135 DIM are not in agreement with data by Cabiddu et al. (1999), as in that paper BCS values increase until the end of lactation, but in their study the goats are reared on a pasture with a higher grass availability also during the summer season and lactation of the goats ends in September.

Plasma urea data was similar to those by Bava et al. (2001) and Min et al. (2005) but lower than those by Brun-Bellut (1996) in lactating Saanen and Alpine goats, by Cabiddu et al. (1999) in goats browsing a Mediterranean shrubland and by Kohn et al. (2005) in various breeds. Plasma urea increased throughout the lactation for LY, whereas it showed a curvilinear shape with the 
highest value from 105 to 135 DIM for IY. In HY, plasma urea showed a particular tendency, with a high value on 45 DIM followed by a drop on 75 DIM, an increase and a new decrease at the end of the trial. The trend of plasma urea was probably affected by the herbage availability and the feed intake, in accordance with the study of Eriksson \& Valtonen (1982) which demonstrate that urea renal excretion declines even if plasma urea rises, for example when feed intake is inadequate and body proteins are utilized as a nitrogen source. In addition, in a study regarding grazing Alpine goats fed different supplementation rates (Min et al. 2005), the highest plasma urea is recorded among the animals which received no concentrate supplementation. Even if the daily milk yield of HY goats was about twice the amount of LY goats throughout all lactation, productive differences were not able to change the urea metabolism of the goats belonging to the different levels as plasma urea values were not affected by the yield level. This characteristic was not in accordance with previous studies regarding the goat (BrunBellut 1996) and, in the cattle species, this is attributable to the function of growth hormone. Indeed, in high milk yielding cows, GH concentrations are higher than those of low-producing ones (Beerepoot et al. 1991) and GH causes N retention, a decrease in N cycling through the digestive tract and a reduction of urinary $\mathrm{N}$ excretion (Reynolds et al. 1992).

In conclusion, in the goats of the present study, milk and plasma urea were not affected by the milk yield level and these results may evidence that genetic improvement of the Sarda goat can be based on milk yielding, without having significative consequences on the metabolism of urea. Extensive breeding of small ruminant species is a common practice of animal husbandry in the Mediterranean area and feed intake is often insufficient, above all in semiarid areas during the hot season. Therefore, it can be suggested to consider milk urea concentration in browsing goat, because measurement of feed, energy and protein intake is impracticable and supplementation is underestimated or cannot be effectively performed as happens in the semi-intensive or intensive production systems.

\section{Acknowledgements}

We are grateful to Karl Max Unterreitmeier for support in German language.

\section{References}

Bauman DE, Currie WB (1980) Partitioning of Nutrients During Pregnancy and Lactation: A Review of Mechanisms Involving Homeostasis and Homeorhesis. J Dairy Sci 63, 1514-1529

Bava L, Rapetti L, Crovetto GM, Tamburini A, Sandrucci A, Galassi G, Succi G (2001) Effects of a nonforage diet on milk production, energy, and nitrogen metabolism in dairy goats throughout lactation. J Dairy Sci 84, 2450-2459

Bedö S, Nikodemusz E, Gundel K, Nagy Z (1997) Relations of plasma concentration of urea, glucose and total protein to milk levels of urea, lactose and protein of grazing ewes during lactation. Arch Tierz 40, 265-275

Beerepoot GM, Freeman AE, Detilleux JC (1991) Effect of season, genetic line, and sire on growth concentrations of somatotropin in serum of Holstein cows in early lactation. J Dairy Sci 74, 3202-3208

Bell AW (1995) Regulation of organic nutrient metabolism during transition from late pregnancy to early lactation. J Anim Sci 73, 2804-2819

Boyazoglu J, Morand-Fehr P (2001) Mediterranean dairy sheep and goat products and their quality: A critical review. Small Rum Res 40, 1-11 
Broderick AG, Clayton MK (1997) A statistical evaluation of animal and nutritional factors influencing concentrations of milk urea nitrogen. J Dairy Sci 80, 2964-2971

Brun-Bellut J (1996) Urea recycling in the rumen of dairy goats: effects of physiological stage and composition of intake. Small Rum Res 23, 83-90

Butler WR, Calaman JJ, Beam SW (1996) Plasma and milk urea nitrogen in relation to pregnancy rate in lactating dairy cattle. J Anim Sci 74, 858-865

Cabiddu A, Branca A, Decandia M, Pes A, Santucci PM, Masoero F, Calamari L (1999) Relationship between body condition score, metabolic profile, milk yield and milk composition in goats browsing a Mediterranean shrubland. Livest Prod Sci 61, 267-273

Caldeira RM, Belo AT, Santos CC, Vazques MI, Portugal AV (2007) The effect of body condition score on blood metabolites and hormonal profiles in ewes. Small Rum Res 68, 233-241

Cannas A, Pes A, Mancuso R, Vodret B, Nudda A (1998) Effect of Dietary Energy and Protein Concentration on the Concentration of Milk Urea Nitrogen in Dairy Ewes. J Dairy Sci 81, 499-508

Carcangiu V, Mura MC, Vacca GM, Bini PP (2006) Sardinian goat breeding and utilisation of environmental resources. In: Ramalho Ribeiro JMC, Horta AEM, Mosconi C, Rosati A (eds.) Animal products from the Mediterranean area, EAAP 119, Wageningen Academic Publishers, Wageningen, The Netherlands 249-254

Cunningham JG (2002) Textbook of veterinary physiology. 3rd edition, WB Saunders Company, PA, USA

Eriksson L, Valtonen M (1982) Renal Urea Handling in Goats Fed High and Low Protein Diets. J Dairy Sci 65, 385-389

FAOSTAT (2008) Statistical Database of the Food and Agriculture Organization of the United Nations on agriculture, nutrition, fisheries, forestry, food aid, land use and population. http://faostat.fao.org [last accessed 18.03.2010]

Fekadu B, Soryal K, Zeng S, van Hekken D, Bah B, Villaquiran M (2005) Changes in goat milk composition during lactation and their effect on yield and quality of hard and semi-hard cheeses. Small Rum Res 59, 55-63

Gustafsson AH, Palmquist DL (1993) Diurnal variation of rumen ammonia, serum urea, and milk urea in dairy cows at high and low yields. J Dairy Sci 176, 475-484

Harmeyer J, Martens H (1980) Aspects of urea metabolism in ruminants with reference to the goat. J Dairy Sci $63,1707-1728$

IZS, Istituto Zooprofilattico Sperimentale dell'Abruzzo e del Molise »G. Caporale« (2008) Italian National Data Bank for the animal husbandry register, founded by the Ministry of Health. http://www.izs.it/IZS/Engine/ RAServePG.php/P/256910010304/L/1 [last accessed 01.03.2011]

Jelínek P, Gajdůšek S, Illek J (1996) Relationship between selected indicators of milk and blood in sheep. Small Rum Res 20, 53-57

Kohn RA, Dinneen MM, Russek-Cohen E (2005) Using blood urea nitrogen to predict nitrogen excretion and efficiency of nitrogen utilization in cattle, sheep, goats, horses, pigs, and rats. J Anim Sci 83, 879-889

Mellado M, Valdez R, Lara LM, García JE (2004) Risk factors involved in conception, abortion, and kidding rates of goats under extensive conditions. Small Rum Res 55, 191-198

Min BR, Hart SP, Sahlu T, Satter LD (2005) The effect of diets on milk production and composition, and on lactation curves in pastured dairy goats. J Dairy Sci 88, 2604-2615

Ngwa AT, Dawson LJ, Puchala R, Detweiler G, Merkel RC, Tovar-Luna I, Sahlu T, Ferrell CL, Goetsch AL (2007) Urea space and body condition score to predict body composition of meat goats. Small Rum Res 73, 27-36

Richardt W, Jeroch H, Spilke J (2001) The impact of nutrition and non nutrition factors on milk urea concentration. II. The impact of non nutrition factors on milk urea concentration. Arch Tierz 44, 505-519 [in German]

Richardt W, Jeroch H, Spilke J (2002) The impact of nutrition and non nutrition factors on milk urea concentration. III. A new milk urea model to indicate the dietary crude protein/energy balance in dairy cows. Arch Tierz 45, 151-157 [in German] 
Roseler DK, Ferguson JD, Sniffen CJ, Herrema J (1993) Dietary Protein Degradability Effects on Plasma and Milk Urea Nitrogen and Milk Nonprotein Nitrogen in Holstein Cows. J Dairy Sci 76, 525-534

Reynolds CK, Lapierre H, Tyrrell HF, Elsasser TH, Staples RC, Gaudreau P, Brazeau P (1992) Effects of growth hormone-releasing factor and feed intake on energy metabolism in growing beef steers: net nutrient metabolism by portal-drained viscera and liver. J Anim Sci 70, 752-763

Sahoo B, Walli TK (2008) Effect of feeding undegradable protein with energy on nutrient utilization, milk yield and milk composition of crossbred goats. Small Rum Res 75, 36-42

Santucci PM, Branca M, Napoleone R, Bouche R, Aumont G, Poisot F, Alexandre G (1991) Body condition scoring of goats in extensive conditions. In: Morand-Fehr P (ed.) Goat Nutrition, EAAP 46, Pudoc Wageningen Academic Publishers, Wageningen, The Netherlands, 240-250

Schepers AJ, Meijer RGM (1998) Evaluation of the utilization of dietary nitrogen by dairy cows based on urea concentration in milk. J Dairy Sci 81, 579-584

Vacca GM, Carcangiu V, Porqueddu M, Dettori ML, Bini PP (2006) Milk yield and composition in Sarda goats and their relations across lactations. In Ramalho Ribeiro JMC, Horta AEM, Mosconi C, Rosati A (eds.) Animal products from the Mediterranean area, EAAP 119, Wageningen Academic Publishers, Wageningen, The Netherlands, 255-260

Wood PDP (1967) Algebraic Model of the Lactation Curve in Cattle. Nature 216, 164-165

Received 29 March 2010, accepted 1 March 2011.

Corresponding author:

Michele Pazzola

email: pazzola@uniss.it

Department of Animal Biology, University of Sassari, Via Vienna 2, 07100 Sassari, Italy 